\title{
Investigating the Effect of Urban New Technologies on the Iranian Lorry Drivers' Behavior
}

\author{
Abdolreza Sheikholeslami (iD, Ehsan Ayazi iD, and Ali Moghadari iD $^{\circ}$ \\ Transportation Engineering, Faculty of Civil Engineering, Iran University of Science and Technology, Tehran, Iran \\ Correspondence should be addressed to Abdolreza Sheikholeslami; sheikh@iust.ac.ir
}

Received 16 July 2020; Revised 16 February 2021; Accepted 7 March 2021; Published 15 March 2021

Academic Editor: Victor L. Knoop

Copyright (C) 2021 Abdolreza Sheikholeslami et al. This is an open access article distributed under the Creative Commons Attribution License, which permits unrestricted use, distribution, and reproduction in any medium, provided the original work is properly cited.

\begin{abstract}
Most accidents are directly related to driving offenses, and drivers who commit more offenses are more prone to accidents. Therefore, reducing driving offenses can reduce accidents. In other words, the recognition of common driving offenses among heavy vehicle (truck) drivers and the effective factors in directing them to reduce driving offenses can consequently reduce the frequency and severity of accidents. It seems that there is a necessity for in-depth studies to carry out research on this topic. The main objective of this study is to identify and evaluate important factors affecting lorry drivers committing traffic offenses. To achieve the goals, the required information was categorized into six categories: traffic tonnage, not fastening the seatbelt, speeding, technical defect, talking on cell phone, and lacking towing worksheet; these factors are known as dependent variables. Also, its influencing factors-in the group of driver characteristics, vehicle, and mileage-were obtained by using a demographic questionnaire, Driving Behavior Questionnaire (DBQ), and interviews with 420 drivers over 60 days at Tehran Terminal. After correcting incomplete questionnaires, 351 drivers' information was used for statistical analysis. The statistical analysis of data using a multivariate logistic regression model showed that drivers loading and unloading five or six times per month are less likely to commit overloading than drivers loading and unloading more than 12 times per month. The results also show that the distracted drivers with less slip behavior are less likely to commit unauthorized speed offenses and $85.4 \%$ are less likely to commit this violation. Finally, the statistical analysis showed that drivers with aggressive driving behavior were more likely to commit a lack of towing worksheet offenses.
\end{abstract}

\section{Introduction}

Today, given the significant transportation activity in the countries' GDP (Gross Domestic Product) and consequently increasing the need for freight and cargo transportation, the importance of the freighter fleet has become increasingly bolder. In Iran, as in other developing countries, commercial transportation, mainly transported by semiheavy and heavy vehicles, plays an important role in the distribution of export and import cargoes. According to the Iran Road Maintenance and Transportation Organization of the Ministry of Roads and Urban Development report in 2017, the volume of goods shipped within the country (annually) equals 428.348 million tonnes and the volume of journeys by trucks is 29.909 million, which has released the index of 224.836 million tonne-kilometers of freight [1].

Drivers' offenses have been one of the major human factors leading to traffic accidents, which have been used in many studies to investigate driving behaviors. According to the Iran Road Maintenance and Transportation Organization of the Ministry of Roads and Urban Development report in 2017, there were 63472 registered violations of which 121108 led to suburban accidents, 16201 led to death, and 33595 led to injury [1].

Meanwhile, lorry drivers due to the different sizes and weights of the vehicle as well as the higher percentage of traffic on the roads as a group of professional drivers have great importance in reducing traffic offenses and subsequent 
accidents. Studies show that heavy-duty driving is among the highest-risk occupations for injury and death [2]. Heavy vehicles have fewer crashes than mileage; however, a very high percentage of traffic crash fatalities are devoted to heavy vehicle accidents [3].

The results of some studies have shown that there is a significant relationship between truck driver offenses and the occurrence of an accident [4]. One of the most important reasons for the increased risk of violations among the lorry drivers that result in more serious crashes is some significant differences between professional and nonprofessional drivers. Most of them, for example, are male and the average age of this $f$ drivers' group is higher than that of the general driver [5]; they drive long and smoothly on the road $[2,6]$ and become tired and drowsy [3, 5, 7-10]. So, understanding the common offenses among lorry drivers and the factors that affect them to reduce offenses and consequently reduce the frequency and severity of accidents makes it more necessary to conduct studies in this regard. The most important contribution of the present research is that this study recognizes the relationship between driving offenses and the lorry driver's driving behavior, driver specification, vehicle, and travel and finally classifies them into six categories: overloading, seat belt, speeding, technical defect, talking on the phone, and lack of towing worksheet.

In spite of the importance and necessity of violations control in the cargo fleet mentioned in the introductory section, so far few studies have been conducted in this regard and of course most of them have used accidents as a parameter to predict accidents or only investigate the relationship between violations and demographic characteristics and the driver sleeping status.

\section{Literature Review}

In a general classification, the whole number of studies on lorry offenses can be classified into three categories, which are referred to in the following.

Some studies have investigated the factors affecting the occurrence of accidents and the investigating models of accident prediction in the field of cargo fleet. One of the most important parameters affecting the occurrence of lorry accidents, which were investigated in previous studies, is the age and the number of hours worked by the driver $[4,6,11-16]$. Researchers have also concluded in other studies that factors such as drowsiness, fatigue, and how salaries are paid increase the risk of accidents [17]. Other variables used in modeling the lorry driver's accidents include driving experience $[4,6,14]$, physical health characteristics $[4,6]$, sleep duration $[11,14,15]$, mileage $[11,14]$, and gender $[4,11-16]$.

Other investigations have also addressed the issue of offenses among lorry drivers and the variables affecting offenses. Driving behavior and individual behavioral characteristics [17-20], driver demographic information [8, 21], mileage $[2,15,22]$, and fatigue and drowsiness $[9,20]$ are emphasized as the parameters considered in this section of studies.
Additionally, one of the most important offenses identified in past studies as a major contributing factor to the occurrence of accidents is speeding. The results show that there is a significant relationship between driving experience and driving offenses such as speeding and not fastening seat belts $[2,3,5,9,18-20,23,24]$. Other studies in this field have found that violations such as long-distance disobedience $[9,24]$, seat belts $[2,5]$, technical defect $[5,23]$, alcohol abuse $[3,5]$, and factors such as accident's history $[2,5,24]$, violations records $[25,26]$, and some parameters of Driving Behavior Questionnaire (DBQ) $[18,19,24]$ have a significant impact on the occurrence of cargo fleet accidents.

In other studies, the effect of driving behavior on committing offenses and its role in the occurrence of lorry driver's accidents are considered. Among the most important parameters to be considered in this section are the four parameters of errors, lapses, common violations, and aggressive violations that in the Drivers Behavioral Questionnaire, the most critical parameter in predicting accidents is distinguished as common violations [20]. Some of the parameters viewed in other studies include the amount of cognitive error [11]; individual rules and perceived behavior control [27]; anger and drivers' differences in driving behavior [18]; mental and emotional conditions while driving; and the drivers' driving style. Overall, studies on the behavior of lorry drivers are summarized in Table 1.

As summarized in previous studies, very few studies have identified the factors associated with the driving behavior of lorry drivers in committing self-reported driving offenses. The most important contribution of the present research is that this study recognizes the relationship between driving offenses and the lorry driver's driving behavior, driver specification, vehicle, and travel and finally classifies them into six categories: overloading, seat belt, speeding, technical defect, talking on the phone, and lack of towing worksheet.

\section{Materials and Methods}

3.1. Sample Information Studied. About 420 questionnaires were prepared to analyze demographic information and heavy vehicle drivers' driving behavior; and among these, 69 of them were eliminated due to deficiencies in answering the questions such as illogical answers, incomplete forms, unreadable questionnaires, and distorted forms. Table 2 presents the characteristics of the participants in this study. Notable points in lorry drivers' characteristics can be technical defect offenses with the highest percentage of repetition among other offenses as well as a significant number of drivers working as single drivers.

3.2. Questionnaire Information. The required information was gathered using two questionnaires. The first questionnaire collected information on demographic characteristics, sleep quality, driver self-reported violations, vehicle, and travel information. Additionally, DBQ was used as a baseline questionnaire. After examining and eliminating the questions, a 21-item survey with 4 factors was used, the details of which are displayed in Table 3. 
TABLE 1: Summary of studies on lorry drivers' behavior offenses.

\begin{tabular}{|c|c|c|c|c|c|}
\hline Authors & Country & The sample & Research method & Analysis & Findings and results \\
\hline $\begin{array}{l}\text { Salmon et al. } \\
{[12]}\end{array}$ & America & $\begin{array}{l}382 \text { questionnaire } \\
\text { completed from } 1065 \\
\text { questionnaires sent to } \\
\text { drivers of transport } \\
\text { companies }\end{array}$ & $\begin{array}{c}\text { Driving Behavior } \\
\text { Questionnaire } \\
\text { (DBQ) }\end{array}$ & Factor analysis & $\begin{array}{l}\text { Four factors (error, mistake, } \\
\text { common violations, and } \\
\text { aggressive violations) were } \\
\text { identified, and only violations } \\
\text { factor showed a significant } \\
\text { relationship with accident } \\
\text { prediction }\end{array}$ \\
\hline
\end{tabular}

$\begin{array}{llll}\text { Davey et al. } & \text { Australia } & \begin{array}{c}443 \text { volunteers, employees } \\ \text { of a large insurance } \\ \text { company in Australia }\end{array} & \text { DBQ }\end{array} \quad \begin{gathered}\text { PCA method for } \\ \text { analyzing DBQ items }\end{gathered}$
are related to aggressive driving behaviors, and the only parameter that can predict the violations is the mileage measured in a year

\begin{tabular}{|c|c|c|c|c|c|}
\hline $\begin{array}{l}\text { Ketabi et al. } \\
{[4]}\end{array}$ & Iran & $\begin{array}{c}300 \text { heavy vehicle drivers in } \\
\text { Yazd }\end{array}$ & DBQ & $\begin{array}{l}\text { Descriptive analysis, } \\
\text { using SPSS, chi-square } \\
\text { analysis, and Pearson } \\
\text { correlation }\end{array}$ & $\begin{array}{l}\text { The more the drivers are affected } \\
\text { by their emotional and mental } \\
\text { states, the more they will likely to } \\
\text { have violations }\end{array}$ \\
\hline $\begin{array}{l}\text { De Winter } \\
\text { et al. [17] }\end{array}$ & America & $\begin{array}{l}\text { Approximately } 6006 \\
\text { professional and } \\
\text { nonprofessional drivers } \\
\text { from } 41 \text { countries }\end{array}$ & DBQ & Linear regression & $\begin{array}{l}\text { Self-reports of violations are } \\
\text { relatively correlated with } \\
\text { self-reports of accidents }\end{array}$ \\
\hline $\begin{array}{l}\text { Mehdizadeh } \\
\text { et al. [16] }\end{array}$ & Iran & $\begin{array}{l}785 \text { valid cases out of } 914 \\
\text { lorry drivers in } 10 \text { provinces }\end{array}$ & DBQ & $\begin{array}{l}\text { Hydrostatic models and } \\
\text { regression and statistical } \\
\text { models }\end{array}$ & $\begin{array}{l}\text { The results of the study confirmed } \\
\text { the four-factor model, including } \\
\text { common violations, aggressive } \\
\text { violations, lapses, and errors }\end{array}$ \\
\hline $\begin{array}{l}\text { Maslak et al. } \\
{[19]}\end{array}$ & Serbia & $\begin{array}{l}918 \text { nonprofessional drivers } \\
\text { and } 504 \text { professional drivers }\end{array}$ & DBQ & $\begin{array}{l}\text { Nonparametric analysis } \\
\text { (PCA) }\end{array}$ & $\begin{array}{l}\text { The results show a correlation } \\
\text { between nonprofessional drivers } \\
\text { and common and aggressive } \\
\text { offenses and errors, while } \\
\text { professional drivers are associated } \\
\text { with positive behaviors }\end{array}$ \\
\hline $\begin{array}{l}\text { Naderi et al. } \\
{[20]}\end{array}$ & Iran & $\begin{array}{l}\text { In-person interview with } \\
474 \text { heavy vehicle drivers }\end{array}$ & DBQ & $\begin{array}{l}\text { Structural equation } \\
\text { modeling (SEM) }\end{array}$ & $\begin{array}{l}\text { To the extent that drivers are } \\
\text { dissatisfied with their sleep } \\
\text { quality, lapses, errors, and } \\
\text { violations increase. Also, the } \\
\text { more expensive the vehicle is, the } \\
\text { less fatigue is felt by the driver }\end{array}$ \\
\hline
\end{tabular}

The scree plot of exploratory factor analysis in Figure 1 shows that the four factors of normal violations, aggressive violations, slips, and risk violations are correctly distinguished.

3.3. Data Collection. In this research, for obtaining a modified DBQ, initially, a 50-question questionnaire (Reference Driving Behavior Questionnaire) was used to gather information about the drivers' driving behavior related to committing driving offenses. Also with the aim of identifying the factors behind the driving behavior, interviews were conducted with 392 heavy vehicle drivers with DBQ, during a 45day interval in Tehran. Subsequently, with the filtering or removing incomplete data, 340 samples were used for statistical analysis and by using exploratory factor analysis with SPSS 22 software, factor loading of questions extracted, the results of which are shown in Table 3 . The information required in this study was obtained through interviewing 420 heavy vehicle drivers in a 60-day interval at Tehran Terminal; then after filtering or removing incomplete questionnaires, 351 drivers' information was used for statistical analysis.
In this study, six types of driving offenses were defined as dependent variables: overweight, seatbelt, speeding, technical defect, talking on the phone, and not having towing worksheet; the factors affecting it were identified in the group of driver characteristics, vehicle, mileage, and driver sleep status as shown in Table 2. Kendall's nonparametric test (discrete variables) was used to investigate the dependence of the independent variables. The results showed that all the independent variables have a correlation coefficient of less than 0.5 , and therefore the independent variables are not highly correlated [11]. All independent variables were classified, and SPSS-22 software was used for statistical analysis.

Figure 2 illustrates the exploratory working model of the study to understand how each variable relates.

\section{Results and Analysis}

In this study, the impact of each independent variable on lorry drivers' offenses was evaluated and the results of the chi-square test are displayed in Table 4 . As indicated by the chi-square test results, all independent variables were 
TABLE 2: Evaluated variables with the frequency of each classification.

\begin{tabular}{|c|c|c|c|c|c|}
\hline Variables & Classes & $\begin{array}{l}\text { Repetition } \\
\text { percentage }\end{array}$ & Variables & Classes & $\begin{array}{l}\text { Repetition } \\
\text { percentage }\end{array}$ \\
\hline \multirow{6}{*}{ Offenses } & Overload & 21.7 & \multirow{6}{*}{$\begin{array}{l}\text { Mileage per year (thousand } \\
\text { kilometers) }\end{array}$} & $0-20$ & 6.1 \\
\hline & Seat belts & 20.4 & & $21-60$ & 14 \\
\hline & Speeding & 15.1 & & $61-100$ & 10.2 \\
\hline & Technical defect & 24.7 & & $101-150$ & 23.5 \\
\hline & Talking on the phone & 14.5 & & $151-200$ & 21.3 \\
\hline & $\begin{array}{c}\text { Not having a towing } \\
\text { worksheet }\end{array}$ & 3.5 & & $>200$ & 24.9 \\
\hline \multirow{2}{*}{$\begin{array}{l}\text { Heavy vehicle } \\
\text { drivers }\end{array}$} & Single driver & 87.5 & \multirow{4}{*}{ Vehicle ownership } & & \\
\hline & Two drivers & 12.5 & & The driver is the owner & 55.1 \\
\hline \multirow{5}{*}{ Heavy vehicle type } & Pickup & 18.4 & & The driver is a partner & 22.1 \\
\hline & Truck & 29 & & $\begin{array}{l}\text { The driver is not the } \\
\text { owner }\end{array}$ & 22.8 \\
\hline & Single axle & 19.2 & \multirow{3}{*}{ How to get income } & $\begin{array}{l}\text { In terms of tonne- } \\
\text { kilometer }\end{array}$ & 44.6 \\
\hline & Pair axle & 11.3 & & By number of services & 33.5 \\
\hline & Thriller & 22.1 & & In hours & 0.4 \\
\hline \multirow{3}{*}{ Marital status } & Single & 14.9 & \multirow{6}{*}{ Discharges and loading per month } & Fixed salary & 21.6 \\
\hline & Married & 85.1 & & One or two & 0.2 \\
\hline & $<30$ & 12.1 & & Three or four & 9 \\
\hline \multirow{3}{*}{ Driver's age } & $30-39$ & 31.4 & & Five or six & 23.7 \\
\hline & $40-49$ & 34.5 & & Seven or eight & 25.6 \\
\hline & $\geq 50$ & 22.1 & & Nine to eleven & 15.7 \\
\hline \multirow{5}{*}{ Education } & High school & 67.8 & \multirow{5}{*}{ Sleep duration in a day } & More than twelve & 25.9 \\
\hline & Diploma & 26.6 & & $<6$ & 36.3 \\
\hline & Advanced diploma & 4.7 & & $6-8$ & 45.9 \\
\hline & Bachelor & 0.9 & & $>8$ & 17.8 \\
\hline & Above bachelor & 0 & & Never & 58 \\
\hline \multirow{5}{*}{ Vehicle’s life } & $1-5$ & 12.2 & \multirow[t]{2}{*}{ Sleep quality (business days) } & Sometimes & 9.1 \\
\hline & $6-10$ & 14.2 & & Always & 22.5 \\
\hline & $11-15$ & 20.6 & \multirow{3}{*}{ Driving experience } & $1-10$ & 31 \\
\hline & $16-20$ & 12 & & $11-20$ & 30.5 \\
\hline & $>20$ & 41 & & $>20$ & 38.5 \\
\hline
\end{tabular}

significant at 95\% confidence level (Sig. < 0.05). The multivariate logistic regression model has been used to analyze the data and identify factors contributing to committing driving offenses. The parent method was used to develop the model in SPSS software. In the first step, all the significant and influential variables in describing the proposed model of this study were identified and inserted into the model.

In the next step, after identifying meaningful variables, multinomial logistic regression modeling has been used to construct the driving offense model. Logistic regression is usually used to categorize discrete variables. These models can be used to categorize binary response variables, such as variables with two solutions, and also can be used for response variables with $r$ category ( $r$ can be greater than 2 ). These models are formatting the $r-1$ logit model for response variables, so that each of the variable's classifications can be compared with the reference classification. In this study, because the dependent variable is a multinomial variable, multinomial logistic regression is used for modeling.

Modeling results of driving offenses for variable types of driving offenses are classified into six categories and listed in Table 5. It should note that, among the offenses expressed here, statistical models of three offenses such as talking on cell phone, speeding, and lack of towing worksheet were eliminated due to a failure to identify the effective variables.

The results in Table 5 show the output of the statistical model in which heavy vehicles that are between 1 and 5 years old are more likely to commit overloading than those which are more than 20 years old. The results of statistical analysis have also shown that drivers who discharge and load five or six times per month are less likely to commit overloading than drivers who do more than 12 times per month and the probability of committing overloading offense is reduced by $87.5 \%$.

The analysis of the results in speeding model shows that drivers who have never forgotten to turn on their car lights are less likely to commit speeding offenses than drivers who always forget to turn on their car lights and the probability of committing speeding violation is reduced by $85.4 \%$.

Furthermore, in analyzing the statistical model of heavy vehicle technical defect offense, it was found that drivers who have never forgotten what gear they are driving are less likely to commit this offense than drivers who always forget about it. So, their probability of committing a technical defect is reduced by $76.8 \%$. Moreover, in the age group of 30-39 years old, the tendency to commit technical defect is higher than the age group of over 50 years. 
TABLE 3: Statistic summary of DBQ information.

\begin{tabular}{|c|c|c|c|}
\hline & Average & $\begin{array}{l}\text { Standard } \\
\text { deviation }\end{array}$ & $\begin{array}{l}\text { Factor } \\
\text { loading }\end{array}$ \\
\hline \multicolumn{4}{|l|}{ Normal offenses } \\
\hline $\begin{array}{l}\text { 1. Without notice, you have crossed some intersections with inappropriate gear (maximum speed allowed) } \\
\text { (Q1) }\end{array}$ & 2.17 & 0.879 & 0.457 \\
\hline 2. You get bored of a slow-moving driver, overtaking him (Q2) & 2.93 & 1.018 & 0.456 \\
\hline 3. You drive near the front car and turn on the lights regularly to get out of your way (Q3) & 1.82 & 0.819 & 0.511 \\
\hline 4. On the two-way route, one decides to overtake the front car in dangerous situations (Q6) & 1.45 & 0.581 & 0.572 \\
\hline 5. You have passed the hazard lamp that has just turned red (Q7) & 1.64 & 0.642 & 0.499 \\
\hline 6. You get angry at the driver's behavior and try to show your anger by turning to him or the beep (Q8) & 2.70 & 0.809 & 0.435 \\
\hline 7. You have largely ignored the legal speed late at night or early in the morning (Q9) & 2.04 & 0.770 & 0.438 \\
\hline 8. To avoid traffic, take the right side of the road and take the overpass (Q15) & 2.04 & 0.914 & 0.487 \\
\hline 9. If you go the wrong way, use the rear axle to get the desired axis (Q17) & 2.01 & 0.793 & 0.422 \\
\hline \multicolumn{4}{|l|}{ Aggressive offenses } \\
\hline 1. You will not let the back car to overtake if he lights or beeps for you (Q14) & 1.86 & 0.741 & 0.528 \\
\hline 2. You do not pay attention to the red light when it is night and late & 1.25 & 0.485 & 0.648 \\
\hline 3. You did not notice pedestrians when turning from the main road to the side road (Q19) & 1.47 & 0.567 & 0.451 \\
\hline 4. Do not let the behind cars that are going to overtake you (Q21) & 1.60 & 0.571 & 0.644 \\
\hline \multicolumn{4}{|l|}{ Risk offenses } \\
\hline 1. You have committed this violation despite the potential for fines due to overloading (Q11) & 2.81 & 0.931 & 0.497 \\
\hline 2. You are sleepy, but you keep on driving because of the short distance remaining (Q12) & 3.02 & 1.038 & 0.523 \\
\hline 3. Sometimes you race against another heavy car or similar car (Q20) & 2.65 & 0.928 & 0.726 \\
\hline \multicolumn{4}{|l|}{ Slips } \\
\hline 1. You have lost the exit of a route and had to turn back a long distance (Q4) & 2.57 & 0.734 & 0.468 \\
\hline 2. Forgetting what gear you are driving and having to check (Q5) & 1.52 & 0.631 & 0.503 \\
\hline 3. Forgot to turn on your car's headlamps and notice that the rest of the cars are flashing for you (Q10) & 1.58 & 0.618 & 0.441 \\
\hline 4. Unable to read traffic sign ongoing to the wrong path (Q13) & 1.89 & 0.721 & 0.453 \\
\hline 5. When you overtake a vehicle, you do not notice it is signaling to the left (Q16) & 1.79 & 0.727 & 0.401 \\
\hline
\end{tabular}

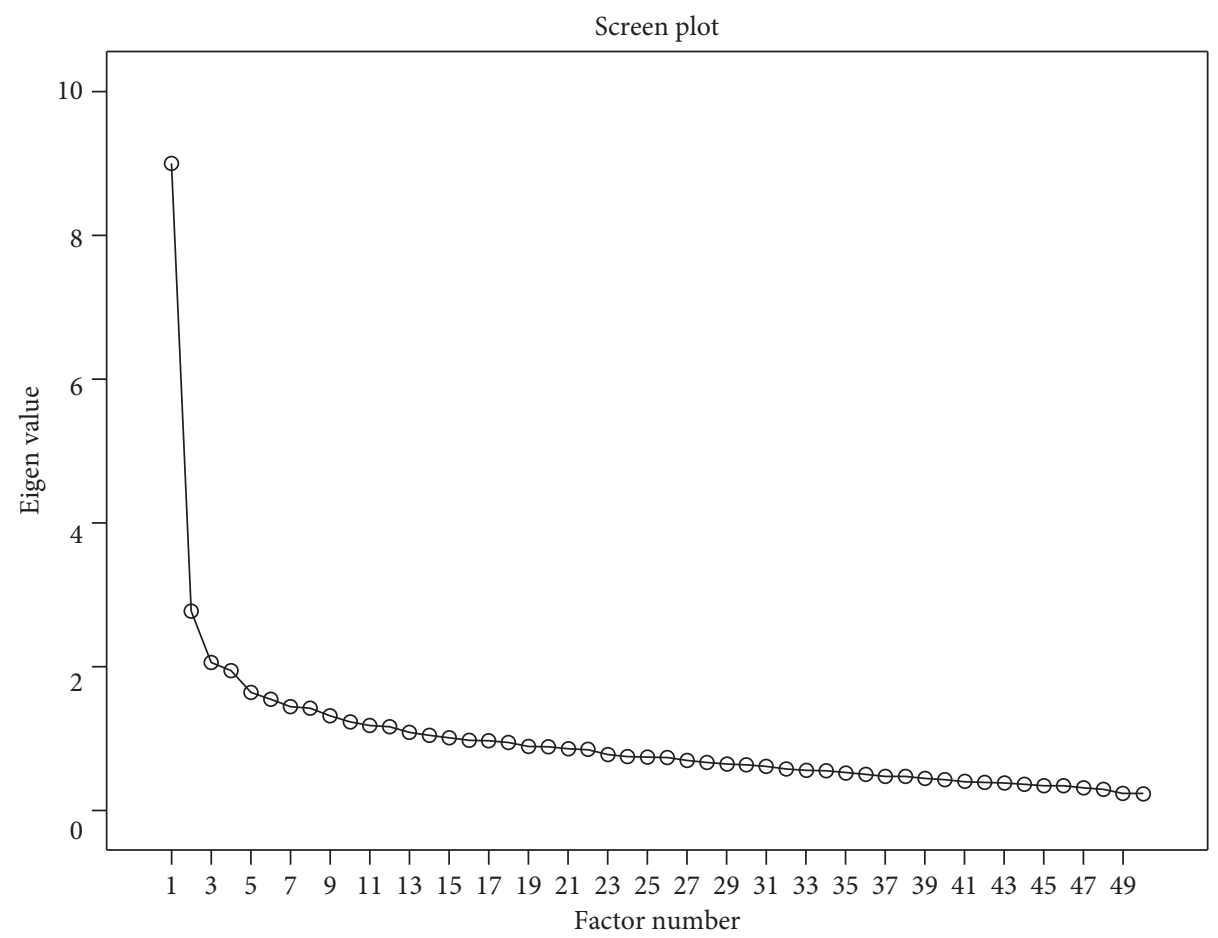

FIgURE 1: Descriptive analysis and identification of factors based on Driving Behavior Questionnaire (DBQ). 


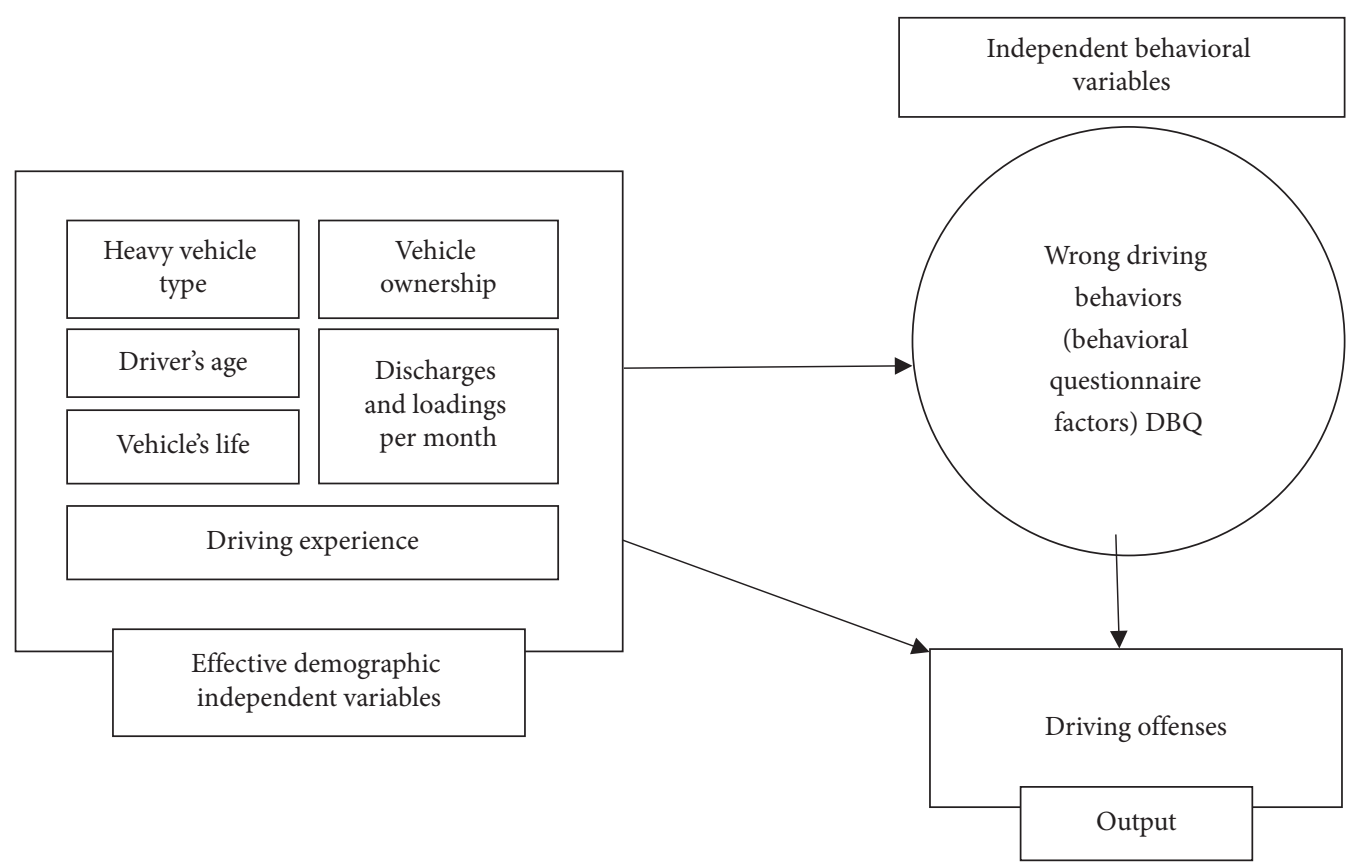

FIgURE 2: The exploratory working model.

TABLE 4: Chi-square test results for independent variables.

\begin{tabular}{lccc}
\hline Variables & Chi-square statistics & Degree of freedom $(\mathrm{d} f)$ & Significance level $($ sig) \\
\hline Heavy vehicle type & 70928 & 20 & 0,000 \\
Driver's age & 40524 & 15 & 0,000 \\
Vehicle's life & 52261 & 20 & 0,000 \\
Driving experience & 14762 & 10 & 0,141 \\
Vehicle ownership & 36099 & 10 & 0,000 \\
Discharges and loadings per month & 73606 & 30 & 0,000 \\
Q1 & 43496 & 15 & 0,000 \\
Q5 & 29515 & 10 & 0,001 \\
Q7 & 51026 & 10 & 0,000 \\
Q10 & 44163 & 10 & 0,000 \\
Q11 & 101303 & 20 & 0,000 \\
Q12 & 59959 & 10 & 0,000 \\
Q16 & 32707 & 10 & 0,000 \\
Q18 & 40127 & 10 & 0,000 \\
Q19 & 38212 & 10 & 0,000 \\
\hline
\end{tabular}

TABLE 5: Results of multivariate regression statistical model analysis.

\begin{tabular}{|c|c|c|c|c|c|c|}
\hline Variable & Category & Reference category & Model coefficient & Standard deviation error & Sig. & Odds ratio \\
\hline \multicolumn{7}{|l|}{ Overloading } \\
\hline Intercept & & & 15.851 & 332.431 & 0.962 & \\
\hline Driver's age (VA) & VA1 & VA5 & 1.368 & 0.641 & 0.033 & 3.927 \\
\hline Discharges and loadings (LU) & LU3 & LU7 & -2.076 & 0.751 & 0.006 & 0.125 \\
\hline \multicolumn{7}{|l|}{ Speeding } \\
\hline Intercept & & & 12.894 & 332.433 & 0.969 & \\
\hline Discharges and loadings (LU) & LU3 & LU7 & -1.746 & 0.823 & 0.034 & 0.174 \\
\hline Vehicle's life (VA) & VA1 & VA5 & 2.135 & 0.661 & 0.001 & 8.455 \\
\hline Driver's age (DA) & DA1 & DA4 & 2.133 & 1.062 & 0.044 & 8.444 \\
\hline LOQ10* & $\mathrm{L} 1$ & L5 & -1.924 & 0.823 & 0.019 & 0.146 \\
\hline \multicolumn{7}{|l|}{ Technical defect } \\
\hline Intercept & & & 1.415 & 451.659 & 0.997 & \\
\hline
\end{tabular}


TABLE 5: Continued.

\begin{tabular}{|c|c|c|c|c|c|c|}
\hline Variable & Category & Reference category & Model coefficient & Standard deviation error & Sig. & Odds ratio \\
\hline Driver's age (DA) & DA2 & DA2 & 1.484 & 0.724 & 0.040 & 4.409 \\
\hline LOQ5 & $\mathrm{L} 4$ & $\mathrm{~L} 4$ & -1.460 & 0.651 & 0.025 & 0.232 \\
\hline \multicolumn{7}{|l|}{ Talking on cell phone } \\
\hline Intercept & & & 11.470 & 332.435 & 0.972 & \\
\hline Driving experience (DE) & DE1 & DE3 & -2.052 & 0.837 & 0.014 & 0.129 \\
\hline LOQ7 & $\mathrm{L} 1$ & L5 & -1.888 & 0.785 & 0.016 & 0.151 \\
\hline \multicolumn{7}{|l|}{ Lack of towing worksheet } \\
\hline Intercept & & & -558.596 & 566.745 & 0.324 & \\
\hline Driver age (DA) & DA1 & DA4 & 61.125 & 27.812 & 0.028 & 854.414 \\
\hline Driving experience (DE) & DE1 & DE3 & -47.711 & 21.957 & 0.030 & 198.149 \\
\hline Vehicle ownership (OOV) & OOV1 & OOV3 & 112.847 & 46.684 & 0.016 & 334.126 \\
\hline LOQ10 & L1 & L5 & -336.766 & 13.391 & 0.016 & 184.127 \\
\hline LOQ19 & L2 & L5 & 267.819 & 109.164 & 0.014 & 246.023 \\
\hline
\end{tabular}

${ }^{*}$ LOQ means the five-point Likert scale of answering the question.

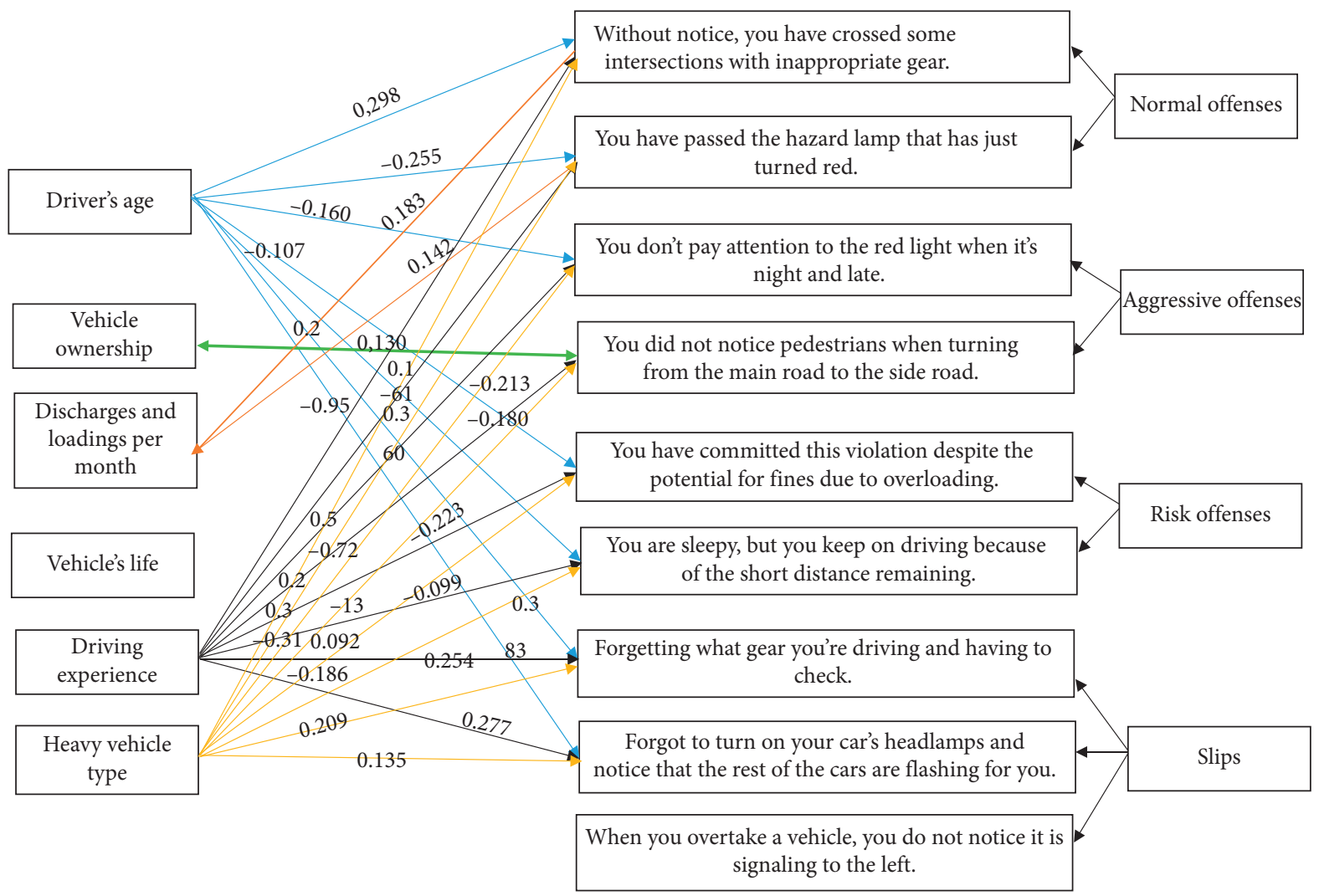

Figure 3: The relationship between independent influential parameters in the utility model and their correlation consequences using the Spearman method.

The results analysis of talking on cell phone model shows that drivers with more than 20 years of driving experience are less likely to commit this offense than drivers who have less than 20 years of experience and the probability of committing this violation is reduced by 87.1 percent.

Finally, the analysis of the model results for lack of towing worksheet revealed that drivers whose type of vehicle is a truck were less likely to commit this offense than those whose vehicle type was a trailer. Statistical analysis additionally showed that drivers who have never forgotten to turn on their car lights were less likely to commit a lack of towing worksheet than drivers who always forgot to turn on their car lights. Also, drivers who have rarely experienced these conditions, who did not notice pedestrians when crossing the main road, were more likely to commit a lack of towing worksheet than drivers who always happened to do so.

In the next section of this study, independent parameters related to drivers' demographic characteristics were used to create the utility model, as well as independent variables 
related to drivers' driving behavior and their related factors used. Therefore, the relationship between these two parts of the independent parameters influencing the model and their correlation is investigated by the Spearman method and shown in Figure 3.

\section{Conclusion}

The main objective of this research is to recognize and assess important factors affecting lorry drivers committing driving offenses. To achieve these goals, the required information was collected during a 60-day interval at Tehran Terminal, through interviewing 420 heavy vehicle drivers, and after filtering or removing incomplete questionnaires, 351 driver's information for statistical analysis was used. It should be noted that, in this study, the six types of driving offenses classified as dependent variables included tonnage overloading, seat belt, speeding, technical defect, talking on cell phone, and lack of towing worksheet, and also the factors affecting it, in the group of driver characteristics, vehicle, and mileage, were identified.

Statistical analysis of the data obtained using a multivariate logistic regression model showed that those drivers who discharge and load five or six times per month are less likely to commit overloading than drivers who do more than 12 times per month and the probability of committing overloading offense is reduced by $87.5 \%$. In other words, according to the study results, increasing the number of discharge-loading times has increased the likelihood of overloading offense. It is possible to reduce the probability of committing driving offenses by limiting the hours of driving and the number of discharge and loading times for drivers in urban areas such as suburban drivers. Therefore, the use of weighing in motion (WIM) scales at urban highways as well as the requirement for freight companies to implement rigorous freight measurements is suggested to reduce overloading, especially on urban roads.

Also, the analysis of the results in the model of speeding shows that drivers who have less slip behavior and are not so distracted are less likely to commit speeding offenses and the probability of violating their speed limit is reduced by $85.4 \%$. In other words, distracting drivers are more likely to commit speeding offenses. This group of drivers appears to be traveling more and more at unauthorized speeds because they have less control over their speed. The result of this study is in accordance with the result of the study done by Naderi Nassiri et al. in 2018 [20] but is against the results obtained by Precht Keinath et al. in 2017 [18].

Furthermore, in analyzing the statistical model of heavy vehicle technical defect offenses, it was found that distracted drivers are more likely to commit traffic violations and the probability of committing their technical defect offenses $s$ is increased by $76.8 \%$. In this regard, it is possible to record the renewal of the driver's license examination by recording vehicle and driver information in the road police system.

Furthermore, in the age group of 30-39 years, the tendency to commit technical defect offense is higher than the age group of 50 years. Finally, the statistical analysis showed that drivers with aggressive driving behavior were more likely to commit a lack of towing worksheet offense.

\section{Data Availability}

The data used to support the findings of this study are available from the corresponding author upon request.

\section{Conflicts of Interest}

The authors declare that they have no conflicts of interest.

\section{References}

[1] E. Ayazi and A. Sheikholeslami, "A data mining approach on lorry drivers overloading in Tehran urban roads," Journal of Advanced Transportation, vol. 2020, Article ID 6895407, 2020.

[2] J. Davey, D. Wishart, J. Freeman, and B. Watson, "An application of the driver behaviour questionnaire in an Australian organisational fleet setting," Transportation Research Part F: Traffic Psychology and Behaviour, vol. 10, no. 1, pp. 11-21, 2007.

[3] J. Reason, A. Manstead, S. Stradling, J. Baxter, and K. Campbell, "Errors and violations on the roads: a real distinction?" Ergonomics, vol. 33, no. 10-11, pp. 1315-1332, 1990.

[4] D. Ketabi, A. Barkhordari, S. J. Mirmohammadi, and A. H. Mehrparvar, "Aberrant behaviors and road accidents among Iranian truck drivers, 2010," Health Promotion Perspectives, vol. 1, no. 2, p. 130, 2011.

[5] T. Rosenbloom, E. Eldror, and A. Shahar, "Approaches of truck drivers and non-truck drivers toward reckless on-road behavior," Accident Analysis \& Prevention, vol. 41, no. 4, pp. 723-728, 2009.

[6] P. E. Fergenson, The Relationship between Information Processing and Driving Accident and Violation Record, SAGE Publications Sage CA, Los Angeles, CA, USA, 1971.

[7] R. Friswell and A. Williamson, "Comparison of the fatigue experiences of short haul light and long distance heavy vehicle drivers," Safety Science, vol. 57, pp. 203-213, 2013.

[8] G. X. Chen, W. K. Sieber, J. E. Lincoln et al., "NIOSH national survey of long-haul truck drivers: injury and safety," Accident Analysis \& Prevention, vol. 85, pp. 66-72, 2015.

[9] J. Thompson, S. Newnam, and M. Stevenson, "A model for exploring the relationship between payment structures, fatigue, crash risk, and regulatory response in a heavy-vehicle transport system," Transportation Research Part A: Policy and Practice, vol. 82, pp. 204-215, 2015.

[10] M. K. Lemke, Y. Apostolopoulos, A. Hege, S. Sönmez, and L. Wideman, "Understanding the role of sleep quality and sleep duration in commercial driving safety," Accident Analysis \& Prevention, vol. 97, pp. 79-86, 2016.

[11] D. Walton, "Examining the self-enhancement bias: professional truck drivers' perceptions of speed, safety, skill and consideration," Transportation Research Part F: Traffic Psychology and Behaviour, vol. 2, no. 2, pp. 91-113, 1999.

[12] M. J. M. Sullman, M. L. Meadows, and K. B. Pajo, "Aberrant driving behaviours amongst New Zealand truck drivers," Transportation Research Part F: Traffic Psychology and Behaviour, vol. 5, no. 3, pp. 217-232, 2002.

[13] L. Brodie, B. Lyndal, and I. J. Elias, "Heavy vehicle driver fatalities: learning's from fatal road crash investigations in Victoria," Accident Analysis \& Prevention, vol. 41, no. 3, pp. 557-564, 2009. 
[14] D. E. Cantor, T. M. Corsi, C. M. Grimm, and K. Özpolat, "A driver focused truck crash prediction model," Transportation Research Part E: Logistics and Transportation Review, vol. 46, no. 5, pp. 683-692, 2010.

[15] J. De Vries, R. De Koster, S. Rijsdijk, and D. Roy, "Determinants of safe and productive truck driving: empirical evidence from long-haul cargo transport," Transportation Research Part E: Logistics and Transportation Review, vol. 97, pp. 113-131, 2017.

[16] M. Mehdizadeh, A. Shariat-Mohaymany, and T. Nordfjaern, "Accident involvement among Iranian lorry drivers: direct and indirect effects of background variables and aberrant driving behaviour," Transportation Research Part F: Traffic Psychology and Behaviour, vol. 58, pp. 39-55, 2018.

[17] J. C. F. De Winter and D. Dodou, "National correlates of selfreported traffic violations across 41 countries," Personality and Individual Differences, vol. 98, pp. 145-152, 2016.

[18] L. Precht, A. Keinath, and J. F. Krems, "Identifying the main factors contributing to driving errors and traffic violations-results from naturalistic driving data," Transportation Research Part F: Traffic Psychology and Behaviour, vol. 49, pp. 49-92, 2017.

[19] M. Maslać, B. Antić, K. Lipovac, D. Pešić, and N. Milutinović, "Behaviours of drivers in Serbia: non-professional versus professional drivers," Transportation Research Part F: Traffic Psychology and Behaviour, vol. 52, pp. 101-111, 2018.

[20] H. Naderi, H. Nassiri, and S. Sahebi, "Assessing the relationship between heavy vehicle driver sleep problems and confirmed driver behavior measurement tools in Iran," Transportation Research Part F: Traffic Psychology and Behaviour, vol. 59, pp. 57-66, 2018.

[21] G. Zhang, Y. Li, M. J. King, and Q. Zhong, "Overloading among crash-involved vehicles in China: identification of factors associated with overloading and crash severity," Injury Prevention, vol. 25, no. 1, pp. 36-46, 2019.

[22] C.-M. Tseng, M.-S. Yeh, L.-Y. Tseng, H.-H. Liu, and M.-C. Lee, "A comprehensive analysis of factors leading to speeding offenses among large-truck drivers," Transportation Research Part F: Traffic Psychology and Behaviour, vol. 38, pp. 171-181, 2016.

[23] D. R. Poulter, P. Chapman, P. A. Bibby, D. D. Clarke, and D. Crundall, "An application of the theory of planned behaviour to truck driving behaviour and compliance with regulations," Accident Analysis \& Prevention, vol. 40, no. 6, pp. 2058-2064, 2008.

[24] M. S. Attarchi, F. Dehghan, S. M. Seyedmehdi, and S. Mohammadi, "Traffic accidents and related injuries in Iranian professional drivers," Journal of Public Health, vol. 20, no. 5, pp. 499-503, 2012.

[25] D. Blower, P. E. Green, and A. Matteson, "Condition of trucks and truck crash involvement," Transportation Research Record: Journal of the Transportation Research Board, vol. 2194, no. 1, pp. 21-28, 2010.

[26] M. Rezapour, S. S. Wulff, and K. Ksaibati, "Predicting truck at-fault crashes using crash and traffic offence data," The Open Transportation Journal, vol. 12, no. 1, 2018.

[27] S. S. Tavafian, T. Aghamolaei, and A. Madani, "Predictors of speeding behavior among a sample of Iranian commercial automobile drivers: an application of the theory of planned behavior," Traffic Injury Prevention, vol. 12, no. 3, pp. 274-278, 2011. 